\title{
Antibacterial and Antifungal Activity of a Snakin-Defensin Hybrid Protein Expressed in Tobacco and Potato Plants
}

\author{
Natalia Kovalskaya ${ }^{1,2}$, Yan Zhao ${ }^{1}$ and Rosemarie W. Hammond ${ }^{1, *}$ \\ ${ }^{I}$ Molecular Plant Pathology Laboratory, U.S. Department of Agriculture, Agricultural Research Service, Beltsville, \\ MD 20705 \\ ${ }^{2}$ Institute of Ecological Soil Science of MV Lomonosov Moscow State University, Moscow 119899, Russia
}

\begin{abstract}
To enhance plant protection against phytopathogens, we constructed a fusion gene (SAP) for the simultaneous production of snakin-1 (SN1) and defensin-1 (PTH1) cysteine-rich antimicrobial proteins originally identified in potato. Prior to in vivo evaluation of antimicrobial activity, SAP produced in Escherichia coli was tested in in vitro against four phytopathogenic microorganisms. SAP exhibited the highest antimicrobial activity against the bacterium Clavibacter michiganensis subsp. sepedonicus, which is the cause of potato ring rot disease, and the anthracnose-causing fungus Colletotrichum coccoides, by complete inhibition of cell growth or spore germination, respectively, at a concentration of 6 $\mu \mathrm{M}$. Notably, SAP showed higher inhibitory activities against Pseudomonas syringae pv. syringae, P. syringae pv. tabaci and Colletotrichum coccoides, than individual SN1 and PTH1, whereas its effect on C. michiganensis subsp. Sepedonicus in in vitro was comparable to that of PTH1 alone. Antimicrobial activity of SAP against C. coccoides and C. michiganensis subsp. sepedonicus was assessed in plants on Nicotiana benthamiana and Solanum tuberosum, respectively, using SAP expressed from the Potato virus $X$-based vectors pP2C2S and/or pGR107. Both SAP-producing plants were significantly more resistant to infection than control plants. Our results demonstrated that in vivo coproduction of recombinant SN1 and PTH1 as a hybrid protein is a promising strategy for antimicrobial plant defense applications.
\end{abstract}

Keywords: Plant antimicrobial proteins, hybrid protein, PVX-based vector, anthracnose, potato ring rot disease, agroinfiltration.

\section{INTRODUCTION}

Phytopathogens attack a wide range of agriculturally important crops, causing significant yield losses. Traditional means of fighting microbial infections in agricultural crop species include application of effective microbicidal chemicals and/or deployment of pathogen resistant cultivars. However, the biologically dynamic nature of plant pathogens leads to the constant emergence of new virulent strains of microorganisms that are either less sensitive to certain microbicidal chemicals or capable of overcoming the existing resistance of plants to those pathogens.

All living organisms, including plants, have evolved diverse inducible or constitutive mechanisms to protect themselves against microbial invasion. These mechanisms in plants include production of proteins (including antimicrobial proteins (AMPs)), secondary metabolites (such as terpenes, phenolics, nitrogen- and sulfur-containing compounds, which are toxic to microbes), reactive oxygen species (such as singlet oxygen, superoxide anion, hydrogen peroxide, and hydroxyl radical, which play an important role in biotic and abiotic stress responses), establishment of

*Address correspondence to this author at the USDA ARS Molecular Plant Pathology Laboratory, Room 214 Building 004 BARC-West, 10300 Baltimore Avenue, Beltsville, Maryland 20705 USA; Tel: (301) 504-5203; Fax: (301) 504-5449; E-mail: rose.hammond@ars.usda.gov structural barriers (such as lignin, tannins, cellulose, and polysaccharides that prevent penetration and colonization of microorganisms) and/or a hypersensitive response that results in programmed death of the infected plant cells, thereby isolating the invading pathogens from the source of nutrients [1-3].

In recent years, AMPs have been the subject of interest as primary candidates for plant protection applications [4]. AMPs exhibit a broad range of activities against bacteria, fungi, viruses and protozoa, with low minimal inhibitory concentrations required, the occurrence of rapid microbial cell damage, and microorganisms that do not acquire resistance to AMPs due to their mechanism of action $[1,5]$. A well-characterized mechanism of action of AMPs is a charged-based interaction of the AMP with phospholipids [6]. Due to the presence of several basic amino acid residues, AMPs are often positively charged at a neutral $\mathrm{pH}$. Electrostatic interactions between positively-charged AMPs and negatively-charged membranes of cellular pathogens could lead to pore formation or disruption of the lipid bilayer, impairing the integrity of the plasma membrane. This unique mode of action makes the induction of resistance in the microorganism difficult because it requires dramatic changes in pathogen phospholipid membrane composition or organization [7-10]. These characteristics make the use of AMPs for developing resistant crops most appealing. 
AMPs include naturally occurring prokaryotic [11-13] and eukaryotic proteins $[8,14-25]$ as well as engineered and synthetic proteins [8, 12, 26, 27]. Although hundreds of plant-produced AMPs have been characterized to date, only a few have been utilized commercially [28]. A comprehensive information about the known natural AMPs can be found online at http://bbcm1.univ.trieste.it/ tossi/ pag1.htm [29] and http://phytamp.pfba-lab.org [30].

Recently, the activities of individual AMPs against a wide range of phytopathogens have been demonstrated in in vitro as well as in vivo [18, 31-39]. In some cases, the simultaneous expression of more than one antimicrobial plant protein has been found to be necessary to achieve a significant level of plant protection [40, 41]. In addition, the use of hybrid proteins of non-plant origin such as cecropinBthanatin and cecropinA-magainin2, cecropinA-melittin and their derivatives has recently been explored as an alternate antimicrobial protein expression strategy [5, 7, 42]. In the case of the cecropinB-thanatin hybrid protein, it possesses an improved biological activity as compared to the individual parental proteins [42]. The derivative of cecropinAmelittin hybrid showed inhibition activity against the plantpathogenic bacteria Erwinia amylovora, Pseudomonas syringae pv. syringae and Xanthomonas vesicatoria at a concentration less than $10 \mu \mathrm{M}[7]$.

In the present work we engineered a hybrid antimicrobial protein from components of plant origin. We fused genes encoding two cysteine-rich AMPs naturally produced in potato plants: snakin-1 (SN1) and defensin-1 (PTH1). SN1 and PTH1 possess different spectra of anti-phytopathogen activities. SN1 is active against both bacterial and fungal species, whereas PTH1 shows primarily antifungal activity $[35,43,44]$. We have also previously shown that individual SN1 and PTH1 proteins possessed significant antimicrobial activity against Clavibacter michiganensis subsp. sepedonicus, Pseudomonas syringae pv. syringae, Pseudomonas syringae pv. tabaci, Colletotrichum coccoides and Botrytis cinerea, all of which cause diseases in vegetable crops; however, in our studies, a clearly defined difference between the spectra of antimicrobial action of both proteins was not observed [31].

The aim of the present study was to develop a genetic strategy for the simultaneous production of SN1 and PTH1 in the form of self-cleavable hybrid protein (SAP) to allow formation of individual SN1 and PTH1 in plant cells. To evaluate the antimicrobial properties of SAP in in vivo we used a transient-expression system based on Potato virus $X$ (PVX)-vectors: pP2C2S and pGR107 [45, 46]. Before performing in vivo experiments, SAP was produced in and purified from Escherichia coli and tested in in vitro on four species of phytopathogenic microorganisms.

\section{MATERIALS AND METHODS}

\section{Plasmid Constructions}

\section{Cloning of Potato sn 1 and pth1 Genes}

Snakin-1 (snl) and defensin-1 (pthl) genes were cloned from stem tissues of young potato seedlings according to standard procedures [47]. Briefly, fresh stem tissues were ground to a powder in liquid nitrogen and total RNA was extracted using a TRI Reagent (Molecular Research Center, Inc. Cincinnati, OH). First strand cDNA was synthesized using primers SN1R and PTH1R (Table 1), respectively, and the double-stranded cDNA was amplified from the first strand cDNA using primer pairs SN1F/SN1R and PTH1F/ PTH1R (Table 1), respectively. The snl gene was cloned into a TA cloning vector pCR2.1 (Invitrogen, Carlsbad, CA) to produce pCRsn1. The pth1 gene was cloned into a plasmid vector pSKII $(+)$ (Stratagene, La Jolla, CA) at the BamHI/HindIII sites resulting in pSKpth1.

\section{Synthesis of FMDV 2a Protease Gene}

The coding sequence of the FMDV 2A protease was generated from the amino acid sequence of the peptide by

Table 1. Oligonucleotide Primers Used for Cloning

\begin{tabular}{|c|c|c|}
\hline Primer & Nucleotide Sequence $\left(5^{\prime} \rightarrow 3^{\prime}\right)^{a}$ & Restriction Sites \\
\hline SN1R & GGAATTCAGGGCATTTAGACTTGC & EcoRI \\
\hline PTH1R & CCCAAGCTTAGCATGGCTTAGTGCA & HindIII \\
\hline SN1F & CTTAGCCATGGTGAAGTTATTTCTATTAAC & NcoI \\
\hline PTH1F & CGGGATCCAGACATTGCGAGTCGTTG & Bam $\mathrm{HI}$ \\
\hline $2 \mathrm{AF}$ & GGAATTCAACTTCGATCTTTTGAAGCTAGCAGGAGATGTTGA & EcoRI \\
\hline $2 \mathrm{AR}$ & CTGGATCCTGGACCTGGATTAGATTCAACATCTCCTGCTAGC & BamHI \\
\hline $\mathrm{SN} 12 \mathrm{~F}$ & CTTAGCCATGGCTGGTTCAAATTTTTGTG & NcoI \\
\hline PTH12R & TAAGAAGCTTTTATCAGCATGGCTTAGTGCAAAAGCA & HindIII \\
\hline PTH12HisR & GCCGCAAGCTTTTATCAGTGATGGTGATGGTGATGGC & HindIII \\
\hline MluKozSPF & CCAGACGCGTCCACCATGGTGAAGTTATTTCTATTA & $M l u \mathrm{I}$ \\
\hline PTH1plt1R & GCGGCCGCTTATCAGCATGGCTTAGTGCAAAA & $\underline{\text { Not I }}$ \\
\hline CMSIF1 & TGTACTCGGCCATGACGTTGG & - \\
\hline CMSIR1 & TACTGGGTCATGACGTTGGT & - \\
\hline
\end{tabular}

${ }^{\mathrm{a}}$ Restriction sites are underlined; nucleotides in italics encode the 6xHis-tag. 
reverse translation [48]. A pair of complementary and partially overlapping primers, $2 \mathrm{AF}$ and $2 \mathrm{AR}$ was designed to synthesize the gene by polymerase chain reaction (PCR) (Table 1). The synthetic $2 a$ protease gene was then cloned into a plasmid vector pUC19 in EcoRI/BamHI sites giving rise to $\mathrm{pUC} 2 a$, which was verified by sequence analysis.

\section{Cloning of the Sap Gene into a PVX-Based Vector pP2C2S}

The multiple cloning site (MCS) of the vector pP2C2S [45]; a gift of Dr. David Baulcombe, Sainsbury Centre, UK) was modified to incorporate additional restriction sites (not shown). The available restriction sites in the expanded MCS included: ClaI , NruI, EcoRV, NcoI, BamHI, EcoRI, HindIII and SalI. To assemble the sn1/2a/pthl expression cassette, the snl gene was first moved from pCRsnl to pP2C2S at the $N c o I / E c o$ RI sites of the expanded MCS, giving rise to $\mathrm{pP} 2 \mathrm{C} 2 \mathrm{~S} / \mathrm{sn} 1$. The $p t h 1$ gene was excised from pSKpthl and ligated to $\mathrm{pUC} 2 a$ at BamHI/HindIII sites giving rise to pUC2apth1. The 2a/pth1 insert was in turn excised from pUC2apth1 and moved to $\mathrm{pP} 2 \mathrm{C} 2 \mathrm{~S} / s n 1$ at EcoRI/HindIII sites. The resulting construct was named $\mathrm{pP} 2 \mathrm{C} 2 \mathrm{~S} /$ sap.

\section{Construction of the pET-Based Expression Cassette}

The coding region of the sap gene was amplified from plasmid pP2C2S/sap using PCR and primer pair SN12F/ PTH12R (Table 1), corresponding to the N- and C-termini of the SAP protein. A carboxy-terminal $6 \times$ His-tagged protein was designed to facilitate purification using a Ni-NTA resin. The primer pair SN12F/PTH12HisR was used to produce this construction. The PCR products were cloned into the $\mathrm{pCR}^{\circledR} \mathrm{II}-$ $\mathrm{TOPO}^{\circledR}$ Vector (Invitrogen), resulting in recombinant plasmids pCRsap and pCRsapHis. These plasmids were subsequently digested with NcoI and HindIII and the corresponding restriction fragments were cloned into the plasmid vector pET26b $(+)$ (Novagen, Madison, WI) at the NcoI/HindIII sites, giving rise to $\mathrm{pET} 26 \mathrm{~b}(+) / s a p$ and $\mathrm{pET} 26 \mathrm{~b}(+) /$ sapHis. All constructions were verified by direct DNA sequencing.

\section{Construction of the Binary PVX-Based Vector pGR107}

The MCS of the vector pGR107 (a gift of Dr. David Baulcombe, Sainsbury Centre, UK; 46) was modified to incorporate additional restriction sites (not shown). The available restriction sites in the expanded MCS included: MluI, CalI , SmalI, SalI, NotI. To assemble the expression cassette, the sap gene was amplified from $\mathrm{pP} 2 \mathrm{C} 2 \mathrm{~S} / \mathrm{sap}$ using primer pair MluKozSPF and PTH1plt1R (Table 1). The sap gene was then cloned into plasmid vector pGR107 at MluI / NotI sites giving rise to $\mathrm{pGR} 107 /$ sap.

\section{Protein Extraction and Characterization}

\section{Protein Expression in Bacteria}

E. coli strain BL21 (DE3) (Stratagene, La Jolla, CA) was used as a host for expression of the target gene. Transformation of $E$. coli by pET26b(+)/sap and pET26b(+)/ sapHis was performed according to the manufacturer's instructions. Protein expression, extraction, inclusion body (IB) purification, solubilization, and refolding were performed as previously described [31].

\section{Protein Extraction from Plants}

The CellLytic ${ }^{\mathrm{TM}} \mathrm{P}$ Plant Cell Lysis/Extraction Reagent (Sigma Chemical Co., Saint Louis, MO) was used to extract total plant protein from plant cells. The extraction was carried out according to the manufacturer's instructions.

\section{Gel Electrophoretic Characterization of Proteins}

Aliquots of the SAP and SAP-His proteins were subjected to electrophoresis in a gradient Novex ${ }^{\circledR}$ TrisGlycine Gel (10 to 20\%; Invitrogen) under denaturing conditions according to the manufacturer's instructions. The proteins were analyzed by staining with SimplyBlue Safe Stain (Invitrogen). The protein concentration was measured with the Quick Start ${ }^{\mathrm{TM}}$ Bradford Dye Reagent (Bio-Rad, Hercules, CA) using a microplate reader (Model 680; Bio$\mathrm{Rad}$ ) [49]. All the extracted proteins were stored at $-20^{\circ} \mathrm{C}$ in $50 \%$ glycerol to prevent freeze-thaw cycles.

\section{Protein Purification with Nickel-Nitrilotriacetic Acid (Ni-NTA) Metal-Affinity Chromatography Matrices}

The Ni-NTA Spin Kit (QIAGEN, Valencia, CA) was used for purification of the target proteins. The purification was carried out according to the manufacturer's instructions.

\section{Western Blot Analysis of Bacterial and Plant Proteins}

To verify the presence of the polyhistidine-tagged SAP (SAP-His), the protein extract was subjected to Western blot analysis. Ten $\mu \mathrm{l}$ of the soluble SAP-His $(2 \mathrm{mg} / \mathrm{ml})$ was loaded on a gradient Novex ${ }^{\circledR}$ Tris-Glycine gel (10-20\%) and transferred to a nitrocellulose membrane (Invitrogen) following electrophoresis. The membrane was incubated with a 1:3000 dilution of monoclonal anti-polyhistidine clone HIS-1 (mouse IgG2a isotype) antibody (Sigma) followed by a 1:5000 dilution of goat anti-mouse phosphataselabeled antibody (Kirkegaard \& Perry Laboratories, Inc., Gaithersburg, MD). The membrane was developed by utilizing the BCIP/NBT Phosphatase Substrate System (Kirkegaard \& Perry Laboratories, Inc.).

To confirm the production of SAP in plants, the total plant protein fraction was subjected to Western blot analysis. Twenty $\mu 1$ of the total plant protein fraction was loaded on a gradient Novex ${ }^{\circledR}$ Tris-Glycine Gel (10-20\%) and transferred to a nitrocellulose membrane (Invitrogen). The membrane was incubated with a 1:200 dilution of polyclonal antiSN1PTH1 (rabbit IgG $(\mathrm{H}+\mathrm{L})$ isotype) antibody (Cocalico Biologicals, Inc., Reamstown, PA) followed by a 1:5000 dilution of goat anti-rabbit phosphatase-labeled antibody (Kirkegaard \& Perry Laboratories, Inc.)

\section{Infection of Plants}

\section{Preparation and Delivery of Infectious Transcripts}

$\mathrm{pP} 2 \mathrm{C} 2 \mathrm{~S} / \mathrm{sap}$ and $\mathrm{pP} 2 \mathrm{C} 2 \mathrm{~S}$, linearized at the SpeI site, were used as templates for the synthesis of capped transcripts in $20 \mu \mathrm{L}$ reaction using $\mathrm{T} 7 \mathrm{mMessage}$ mMachine kit (Ambion, Inc., Austin, TX). The transcripts were diluted twice with $50 \mathrm{mM} \mathrm{K} \mathrm{HPO}_{4}(\mathrm{pH}$ 7.2) and rubbed onto leaves (rub-infection) of experimental plants using carborundum. Three leaves were infected for each plant. The plants of Nicotiana benthamiana were infected at 4-5-leaf stage, Solanum tuberosum - at 3 weeks age. All rub-infected plants were grown in a green house at $27 \pm 2^{\circ} \mathrm{C}$ under 18-h/6-h light/dark photoperiod for 10 ( $N$. benthamiana) or 14 ( $S$. tuberosum) days until inoculation by pathogenic microorganisms. 


\section{Preparation of Agrobacterium Competent Cells}

Five $\mathrm{ml}$ of LBG (LB medium supplemented with $0.4 \%$ glucose) with tetracycline $(10 \mu \mathrm{g} / \mathrm{ml}$, final concentration) was inoculated by Agrobacterium tumefaciens strain GV3101 containing helper plasmid pJIC SA_Rep and grown at $28^{\circ} \mathrm{C}$ overnight at $250 \mathrm{rpm}$. Five $\mathrm{ml}$ of overnight culture was added to $50 \mathrm{ml} \mathrm{LBG}$ (with tetracycline) and agitated at $250 \mathrm{rpm}$ at $28^{\circ} \mathrm{C}$ until the culture density reached $\mathrm{OD}_{600}$ of 0.5 to 1.0 ( $\sim$ hrs). After chilling for $10 \mathrm{~min}$ on ice the culture was centrifuged at $4000 \mathrm{rpm}$ for $20 \mathrm{~min}$ at $4^{\circ} \mathrm{C}$. The pellet was resuspended in $1 \mathrm{ml}$ of $20 \mathrm{mM}$ of ice-cold $\mathrm{CaCl}_{2}$ solution and $0.1-\mathrm{ml}$ aliquots of cell suspension were dispensed into pre-chilled Eppendorf tubes and stored at $-80^{\circ} \mathrm{C}$.

\section{Introduction of pGR107/Sap and pGDp19 into A. Tumefaciens}

One $\mu \mathrm{g}$ of either pGR107/sap or pGDp19 [expressing a viral silencing suppressor protein, 50] plasmid DNA was added to the thawed competent cells and frozen in liquid nitrogen for $5 \mathrm{~min}$. Heat shock was performed at $37^{\circ} \mathrm{C}$ for 25 min. The cells were supplied with $1 \mathrm{ml}$ of LBG medium containing tetracycline followed by incubation at $28^{\circ} \mathrm{C}$ for 3 hours with shaking at $150 \mathrm{rpm}$. The tubes were centrifuged for $30 \mathrm{~s}$ at maximum speed and the pellets were resuspended in $50 \mu \mathrm{l}$ of LBG medium and spread on an LBG agar plates containing tetracycline $(10 \mu \mathrm{g} / \mathrm{ml})$ and kanamycin $(50 \mu \mathrm{g} / \mathrm{ml})$. The plates were incubated at $28^{\circ} \mathrm{C}$ for 5 days. The positive agrobacterium colonies were reconfirmed by PCR before agroinfiltration.

\section{Agroinfiltration}

Five $\mathrm{ml}$ of $\mathrm{LBG}$ medium containing tetracycline $(10 \mu \mathrm{g} / \mathrm{ml}$, final concentration) and kanamycin $(50 \mu \mathrm{g} / \mathrm{ml}$, final concentration) was inoculated with transformed agrobacterium cells and incubated overnight at $28^{\circ} \mathrm{C}$ at 250 $\mathrm{rpm}$. The cultures were centrifuged at $4000 \mathrm{rpm}$ at $25^{\circ} \mathrm{C}$ for $20 \mathrm{~min}$ and the bacterial pellets were gently re-suspended in infiltration medium (10 $\mathrm{mM} \mathrm{MgCl} 2,10 \mathrm{mM}$ MES pH5.7, $150 \mu \mathrm{M}$ acetosyringone) to an $\mathrm{OD}_{600}$ of $0.5-1.0$ and left at ambient temperature for 3 hours. Prior to the infiltration procedure, one part of the silencing suppressor pGDp19 [50] and 9 parts of pGR107/sap were mixed. N. benthamiana plants at leaf stage 4-5 were used for infiltration. Leaves were agroinfiltrated at the abaxial side with the bacterial suspension using a 1-ml needle-less syringe. Two leaves were infiltrated per plant. Infiltrated plants were maintained in a green house at $27 \pm 2^{\circ} \mathrm{C}$ under $14-\mathrm{h} / 10$-h light/dark photoperiod for 7 days until inoculation by $C$. coccoides.

\section{Studies with Microorganisms}

\section{Microorganisms}

The list of the microorganisms used in experiments is displayed in (Table 2).

C. michiganensis subs. sepedonicus (hereinafter referred to as $C$. michiganensis), a Gram-positive bacterium, causing potato ring rot disease, was grown on nutrient-broth yeast extract agar (NBY) [8.0g of nutrient broth (Difco, Detroit), $2.0 \mathrm{~g}$ of yeast extract, $2.0 \mathrm{~g}$ of $\mathrm{K}_{2} \mathrm{HPO}_{4}, 0.5 \mathrm{~g}$ of $\mathrm{KH}_{2} \mathrm{PO}_{4}$, $2.5 \mathrm{~g}$ of glucose and $15.0 \mathrm{~g}$ of Bacto agar per 1 liter of $\mathrm{H}_{2} \mathrm{O}$; after autoclaving, $1.0 \mathrm{ml}$ of a sterile solution of $1 \mathrm{M} \mathrm{MgSO}_{4}$ was added]. After inoculation of solid medium with the bacterium, the plates were incubated for five days at $28^{\circ} \mathrm{C}$. For antibacterial assays the colonies from the plate were transferred into a culture tube containing NBY broth and grown at $28^{\circ} \mathrm{C}$ with vigorous shaking at $250 \mathrm{rpm}$ for 168 hours.

P. syringae pv. syringae and $P$. syringae pv. tabaci, Gram-negative bacteria, were grown on KB medium [20.0 g of Proteose peptone \#3 (Difco, Detroit, MI), $1.5 \mathrm{~g} \mathrm{~K}_{2} \mathrm{HPO}_{4}$, $15.0 \mathrm{ml}$ glycerol, $15.0 \mathrm{~g}$ Bacto agar per liter $\mathrm{H}_{2} \mathrm{O}$; after autoclaving, $6.0 \mathrm{ml}$ of a sterile solution of $1 \mathrm{M} \mathrm{MgSO}_{4}$ was added] [51]. The culture plates were incubated for two days at $28^{\circ} \mathrm{C}$. For antibacterial assays the colonies from the plate were transferred into a tube containing $\mathrm{KB}$ broth and grown at $28^{\circ} \mathrm{C}$ with shaking $(250 \mathrm{rpm})$ overnight.

Colletotrichum coccoides causing anthracnose of various plant species was routinely cultured on Potato Dextrose Agar (PDA) (Difco) plates for approximately 14 days at room temperature. For antifungal assays in in vitro and in vivo, the spores were collected and suspended in Potato Dextrose Broth (PDB) (Sigma-Aldrich, Inc., St. Louis, MO) or distilled sterile water, respectively. Spore concentrations were determined using hemacytometer and light microscope (Zeiss Axioskop 2).

Table 2. Organisms and Constructions Used in In Vivo Experiments

\begin{tabular}{|c|c|c|c|}
\hline Phytopathogens & Plants & \multicolumn{2}{|c|}{ Constructions and Their Delivery into the Plants } \\
\hline \multicolumn{4}{|l|}{ Bacteria } \\
\hline Clavibacter michiganensis subsp. sepedonicus AS1 & Solanum tuberosum & $\begin{array}{l}\mathrm{pP} 2 \mathrm{C} 2 \mathrm{~S} \\
\mathrm{pP} 2 \mathrm{C} 2 \mathrm{~S} / \text { sap }\end{array}$ & transcript infection \\
\hline Pseudomonas syringae pv. syringae 61 & $\mathrm{n} / \mathrm{a}$ & $\mathrm{n} / \mathrm{a}$ & $\mathrm{n} / \mathrm{a}$ \\
\hline Pseudomonas syringae pv. tabaci 11528 Race 0 & $\mathrm{n} / \mathrm{a}$ & $\mathrm{n} / \mathrm{a}$ & $\mathrm{n} / \mathrm{a}$ \\
\hline Fungus & & $\begin{array}{l}\mathrm{pP} 2 \mathrm{C} 2 \mathrm{~S} \\
\mathrm{pP} 2 \mathrm{C} 2 \mathrm{~S} / \text { sap }\end{array}$ & transcript infection \\
\hline Colletotrichum coccoides & Nicotiana benthamiana & $\begin{array}{l}\text { or } \\
\text { pGR107 } \\
\text { pGR107/sap }\end{array}$ & agroinfiltration \\
\hline
\end{tabular}




\section{Antibacterial Assays}

\section{$\underline{\text { In Vitro Assay }}$}

The antibacterial activity of SAP protein recovered from IBs was determined against $C$. michiganensis, $P$. syringae pv. syringae, $P$. syringae pv. tabaci as previously described [31], using $0,0.6,1.2,3.0$ and $6.0 \mu \mathrm{M}$ in $1 \mathrm{ml}$ of total reaction volume. The bacterial concentration in the beginning of the experiment was $1 \times 10^{4} \mathrm{CFU}$ per $\mathrm{ml}$ for $C$. michiganensis, $4 \times 10^{5} \mathrm{CFU}$ per $\mathrm{ml}$ for $P$. syringae $\mathrm{pv}$. syringae and $8 \times 10^{4}$ CFU per $\mathrm{ml}$ for $P$. syringae $\mathrm{pv}$. tabaci.. The reaction mixtures were incubated at $28^{\circ} \mathrm{C}$ with continuous aeration at $250 \mathrm{rpm}$ for 192 and 17 hours for $C$. michiganensis and pseudomonades, respectively. Following the incubation, $100 \mu \mathrm{l}$ aliquots of protein-treated bacterial cultures were serially diluted in sterile water (from $10^{-2}$ to $10^{-6}$ ) and $25 \mu \mathrm{l}$ of diluted bacterial suspensions were plated onto the appropriate solid medium. The plates were incubated at $28^{\circ} \mathrm{C}$ for 5 and 2 days for C. michiganensis and pseudomonades, respectively and examined for bacterial growth by counting CFU. Each protein concentration was analyzed in triple replication.

\section{$\underline{\text { In Vivo Assay }}$}

Transcript-infected plants of Solanum tuberosum (redskinned variety) were inoculated by $C$. michiganensis in two different procedures. The first procedure involved injection of the plant stems with $C$. michiganensis at a single site with $100 \mu \mathrm{L}$ of bacterial suspension $\left(10^{8} \mathrm{CFU} / \mathrm{ml}\right)$ in sterile distilled water. The second procedure involved trimming of the plant roots to remove about $1 / 3$ of root mass and their immersion in bacterial suspension $\left(7 \times 10^{6} \mathrm{CFU} / \mathrm{ml}\right)$ for 30 min followed by planting in soil. Bacterial suspension ( 7 days old) was centrifuged at $20^{\circ} \mathrm{C}$ for $15 \mathrm{~min}$ at $4000 \mathrm{rpm}$; with which the cell pellet was washed twice with and finally resuspended in sterile water. The plants were grown in green house at $27 \pm 2^{\circ} \mathrm{C}$ under 14 -h/10-h light/dark photoperiod.

\section{Antifungal Assays}

\section{$\underline{\text { In Vitro Assay }}$}

The antifungal activity of SAP against $C$. coccoides was determined by counting germinating and non-germinating protein-treated fungal spores, as previously described [31], using a concentration of SAP protein adjusted by PDB so that final concentrations were 0 (control), 0.6, 1.2, 3.0 and $6.0 \mu \mathrm{M}$. Each antifungal assay was performed in three replicates. The total volume of protein-fungus mixture was $50 \mu 1$. Twenty five $\mu 1$ of each mixture was applied on the surface of a hemacytometer, which was placed into a humidifying chamber (Petri dish with wet filter paper). The inhibitory activity of SAP on spore germination was determined after 12 hours of incubation at $28^{\circ} \mathrm{C}$ by visualization with light microscopy.

\section{In Vivo Assay}

$N$. benthamiana plants were inoculated with a suspension of $10^{6}$ conidia $\mathrm{ml}^{-1}$ of $C$. coccoides in sterile distilled water by spraying until the fluid runoff. The plants were enclosed in a plastic box, incubated at $27 \pm 2^{\circ} \mathrm{C}$ under $14-\mathrm{h} / 10-\mathrm{h}$ light/dark photoperiod, and monitored daily for the disease symptoms. Each inoculation experiment was repeated four times.
Light microscopy. Sections of the tobacco leaves containing infection sites were excised and placed on a glass slide with several drops of lactophenol cotton blue solution and heated over a flame for approximately $10 \mathrm{~s}$. Stained leaf pieces were examined by light microscopy (Zeiss, Axioskop 2).

\section{Molecular Analysis of the Plants Expressing the Sap Gene}

\section{$\underline{R T-P C R}$ for Detection of Sap in Plant Tissues}

Total cellular RNA was extracted using TRI Reagent (Molecular Research Center, Inc.) from systemically infected leaves of tobacco and potato plants one/two weeks after infection by PVX transcripts, respectively. The RT-PCR analysis was carried out using Titan One Tube RT-PCR System (Roche, Germany) according to the manufacturer's instructions with the primer pair SN1F/PTH1R at concentration 20 pmol, annealing temperature $52^{\circ} \mathrm{C}$ and elongation time of $2 \mathrm{~min}$. For RT-PCR, 35 cycles were conducted in a GeneAmp ${ }^{\circledR}$ System 9700 (Applied Biosystems, US) with AMV reverse transcriptase for the first strand cDNA synthesis and the Expand High Fidelity enzyme blend consisting of Taq DNA polymerase and Tgo DNA polymerase for amplification of cDNA by PCR. The PCR fragments were fractionated on a $1.0 \%$ agarose gel.

\section{Detection of $C$. Michiganensis in Potato Tubers by PCR Analysis}

The samples of DNA were extracted from the potato tubers 40 days after inoculation by $C$. michiganensis using Plant DNAzol ${ }^{\circledR}$ Reagent (Invitrogen) [52]. C. michiganensis subsp. sepedonicus- specific DNA sequence was amplified by primer pair CMSIF1/CMSIR1 ([53]; Table 1). These primer pairs were designed on the sequence of the $1.3-\mathrm{kb}$ insertion element IS1121, a highly repeated segment of DNA that is present in the chromosome of $C$. michiganensis subsp. sepedonicus [54, 55]. For PCR amplification, 35 cycles were conducted in a GeneAmp®System 9700 (Applied Biosystems, US) with AmpliTaq polymerase. The following PCR parameters were used: denaturation at $94^{\circ} \mathrm{C}$ for $1 \mathrm{~min}$ ( $5 \mathrm{~min}$ for the first cycle), annealing for $2 \mathrm{~min}$ at $34^{\circ} \mathrm{C}$ and extension for $3 \mathrm{~min}(10 \mathrm{~min}$ in the final cycle) at $72^{\circ} \mathrm{C}$. Formamide (final concentration, $3 \%$ ) was added to the reaction mixture. The PCR fragments were fractionated in a $1.0 \%$ agarose gel.

\section{RESULTS}

\section{Expression of Sap in a Prokaryotic Expression System}

To obtain a purified recombinant SAP protein, we positioned the sap gene expression cassette in the pET26b(+) vector under the control of a bacteriophage $\mathrm{T} 7$ promoter (Fig. 1A). The core of the expression cassette was a single open reading frame encoding the hybrid SAP protein. To allow formation of individual $\mathrm{SN} 1$ and $\mathrm{PTH} 1$ proteins, the autocatalytic cleavage site of the foot-and-mouth disease virus (FMDV) 2A protease oligopeptide [48, 56] was incorporated between $s n 1$ and pthl sequences of the hybrid gene. Analysis of the total and soluble fractions of bacterially-expressed SAP protein by gel electrophoresis demonstrated that SAP was localized in the insoluble fraction containing inclusion bodies (IBs) (Fig. 2A). Our attempts to express the protein at a lower temperature $\left(25^{\circ} \mathrm{C}\right)$ 


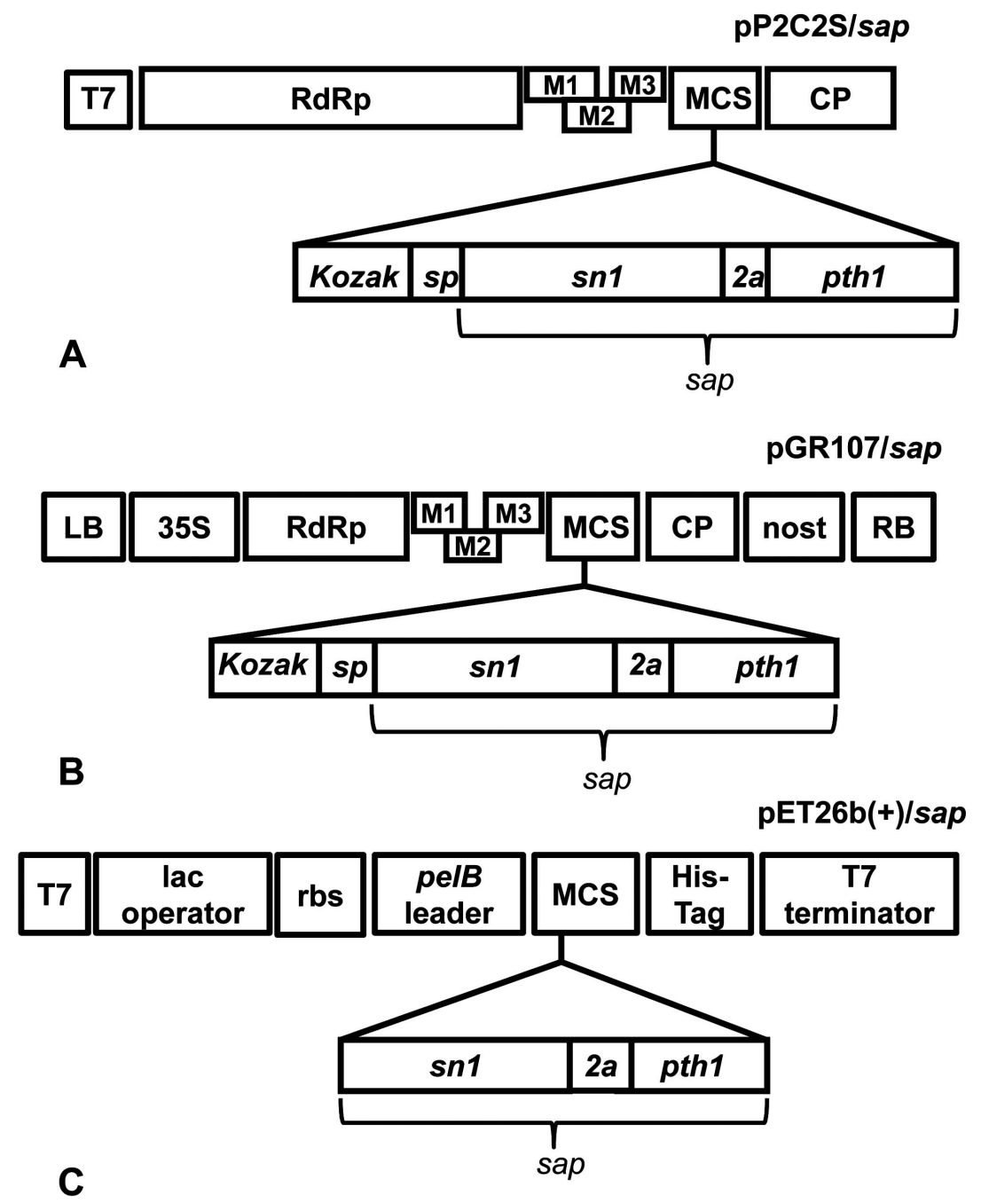

Fig. (1). Schematic representation of vector constructions carrying engineered genes snl and pth1 in the form of hybrid gene sap. The cloning/expression region of $\mathrm{pET}-26 \mathrm{~b}(+) /$ sap vector indicating the insertion of the sap gene. (A). pET-26b(+) carries an N-terminal pelB signal sequence for potential periplasmic localization, plus optional C-terminal His-Tag sequence. rbs - ribosomal binding site sequence. Genome organization of PVX-based vectors carrying the sap gene: pP2C2S/sap (B) and pGR107/sap (C). Features shown are: T7 bacteriophage (T7) and Cauliflower mosaic virus 35S (35S) promoters; viral RNA-dependent RNA polymerase gene (RdRp); "triple gene block" encoding three specific movement proteins of PVX: M1, M2, M3; multiple cloning site (MCS); coat protein (CP); nopaline synthase transcriptional terminator (nost); T-DNA left and right borders (LB, RB); genes for signal peptide ( $s p$ ) to facilitate the localization of hybrid to the periplasm, SN1 (snl), FMDV 2A protease oligopeptide (2a), PTH1 (pthl) and SAP (sap).

to avoid IB formation or extraction of the protein from IBs using sonication or solubilization with $8 \mathrm{M}$ urea failed (data not shown). After solubilization, IBs were analyzed by gel electrophoresis. The size of the protein recovered from IBs was consistent with the predicted molecular mass of SAP of approximately $14 \mathrm{kDa}$. Despite of our expectation of generating two individual SN1 and PTH1 proteins from the hybrid, no visible cleavage products were observed (Fig. 2B).

Another variant of SAP containing a carboxy-terminal six histidine (6His) tag (SAPHis) was generated in parallel to allow affinity purification of the protein. To verify the presence of the polyhistidine tag in SAP this protein was subjected to Western blot analysis using a monoclonal antipolyhistidine antibody. The results confirmed the presence of polyhistidine in the expressed protein (data are not shown). However, our attempts to purify SAPHis on Ni-NTA resin after IB solubilization and protein refolding were unsuccessful, most likely due to some conformational alterations in this protein following it's refolding. These alterations could result in the internalization of the 6 His tag inside the protein structure rendering it inaccessible for binding to the resin. For this reason the SAP variant without polyhistidine was used for all microbiological assays of this study.

\section{Analysis of the Antimicrobial Activity of SAP in in Vitro}

To assess the antimicrobial activity of the SAP protein, we performed a number of antibacterial and antifungal growth inhibition assays as described in Materials and Methods. The growth of $C$. michiganensis, $P$. syringae pv. syringae, $P$. syringae pv. tabaci and spore germination of $C$. coccoides were affected by SAP (Fig. 3). Among the tested bacteria $C$. michiganensis was the most susceptible to the hybrid protein as its growth was completely inhibited by SAP at a concentration of $6 \mu \mathrm{M}$. The pseudomonads showed 


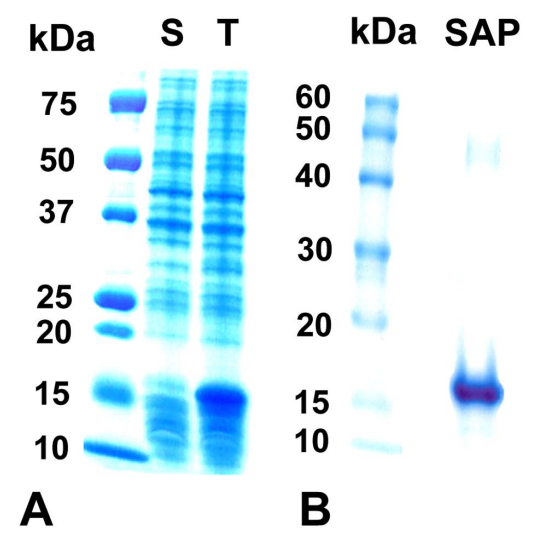

Fig. (2). Denaturing 10-20\% polyacrylamide gel electrophoretic analysis of A: soluble (S) and total (T) fractions of SAP produced in E. coli transformed by pET26b(+)/sap. Sample lanes contain $4 \mu \mathrm{g}(\mathrm{S})$ and $5 \mu \mathrm{g}(\mathrm{T})$ of protein. $\mathrm{kDa}=$ Precision Plus Protein Kaleidoscope standards (Bio-Rad). The gel was stained with SimplyBlue Safe Stain (Invitrogen); B: SAP after IB purification, solubilization and protein refolding. Sample lane contains $10 \mu \mathrm{g}$ of SAP. $\mathrm{kDa}=$ BenchMark $^{\mathrm{TM}}$ His-tagged Protein standards (Invitrogen).

a less sensitivity to SAP where $6 \mu \mathrm{M}$ of SAP led to about $20 \%$ and $30 \%$ inhibition of growth of $P$. syringae pv. syringae and $P$. syringae pv. tabaci, respectively. Antifungal activity of SAP revealed that $6 \mu \mathrm{M}$ of SAP led to a complete inhibition of the spore germination of C. coccoides (Fig. 3).

Comparative analysis of activities of individual SN1 and PTH1 proteins [31] with the hybrid protein is represented in (Fig. 4). The effect of SAP on growth of C. michiganensis was comparable to the effect of PTH1 alone, suggesting that the activity of the hybrid protein, in this case, was primarily determined by PTH1 component of the hybrid; however, aggregation of the bacterial cells in cultures of $C$. michiganensis by SAP was similar to that observed with SN1 alone (data not shown) [31], indicating that the SN1 protein was active in the hybrid protein. In contrast, an additive effect of SAP inhibitory activity on growth was observed against $P$. syringae pv. syringae, $P$. syringae pv. tabaci and $C$. coccoides.

Microorganisms that were shown in in vitro experiments to exhibit the highest sensitivity to the hybrid SAP protein at the lowest concentrations were chosen for testing in vivo. They were the bacterium $C$. michiganensis and the fungus $C$. coccoides.

Expression of the Sap Gene in N. Benthamiana and Analysis of Antifungal Activity of SAP Protein Against $C$. Coccoides in in Vivo

For in vivo assays, the sap gene expression cassette was engineered into the PVX-based vector pP2C2S [45] and binary PVX-based vector pGR107 [46], under the control of bacteriophage $\mathrm{T} 7$ and Cauliflower mosaic virus $35 \mathrm{~S}$ promoters, respectively $(\mathrm{Fig}$. $\mathbf{1 B}, \mathbf{C})$, and delivered into plants as described (Materials and Methods). The stability of the engineered sap gene within both PVX-based vectors in tobacco plants was confirmed by RT-PCR assays performed on RNA samples isolated from systemically infected leaves on 9/7 days after transcript infection/agroinfiltration, respectively (Fig. 5A). Expression of the sap gene in plant tissues was confirmed by Western blot analysis in the case of agroinfiltration with the pGR107/sap vector (Fig. 5B), whereas in case of transcript infection with the $\mathrm{pP} 2 \mathrm{C} 2 \mathrm{~S} / \mathrm{sap}$ vector no detectable level of SAP protein in plant cells was observed (data not shown). Moreover, the employed expression strategy was expected to generate two individual antimicrobial proteins SN1 and PTH1 from the hybrid in in vivo but no visible cleavage products were detected (Fig. 5B), and similar to what was observed in E. coli (Fig. 2B).

The following treatments for antifungal assays were used: 1) "control-mock" (plant + C. coccoides); 2) "emptyPVX" (plant + pP2C2S or pGR107 + C. coccoides) and 3) "PVX/sap" (plants + pP2C2S/sap or pGR107/sap + C. coccoides). Anthracnose symptoms appeared in all

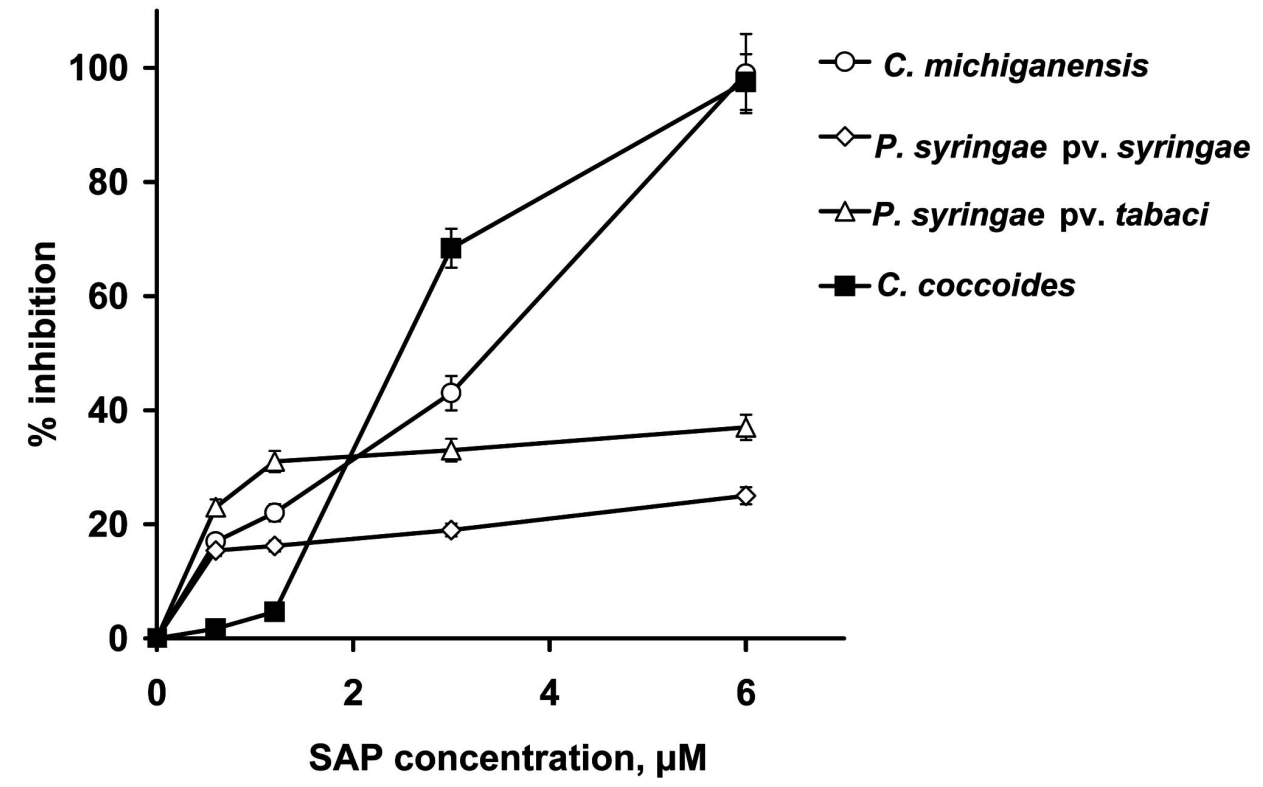

Fig. (3). The antimicrobial effect of SAP on various phytopathogenic microorganisms in vitro. \% inhibition on the $\mathrm{Y}$-axis refers to colonyforming units (CFU) for bacteria (C. michiganensis, $P$. syringae pv. syringae, $P$. syringae pv. tabaci) and spore germination for fungus $C$. coccoides. Each result is a mean of three replications. Values are expressed as means $\pm 5 \%$. 


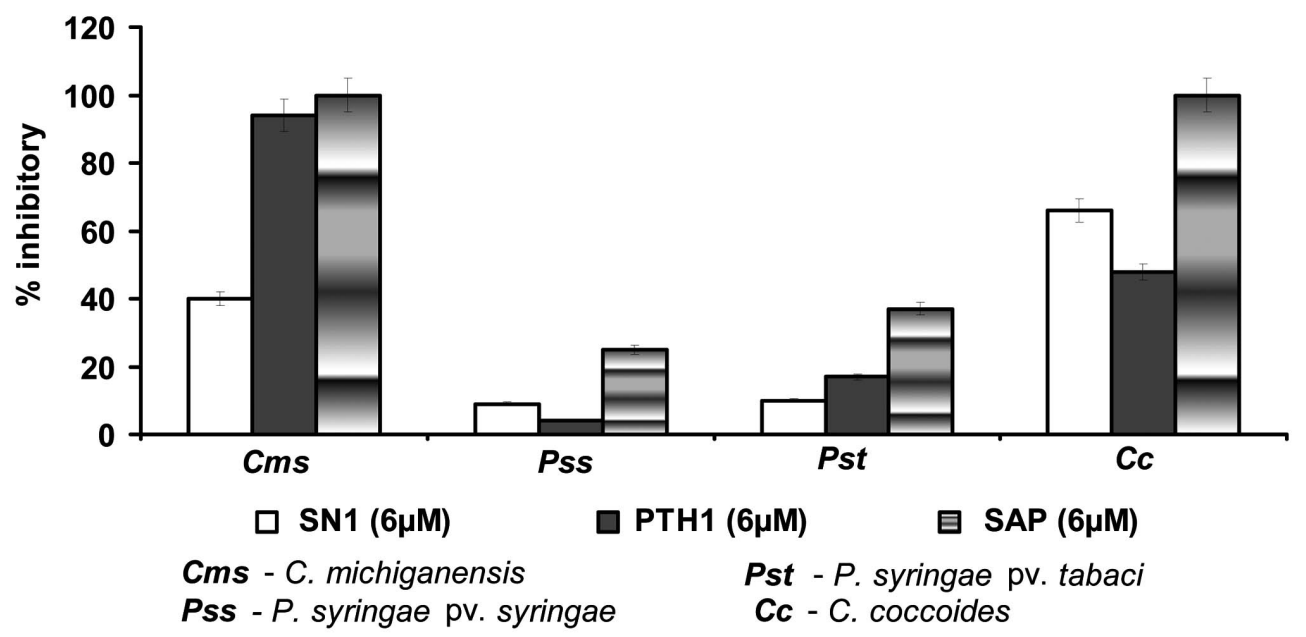

Fig. (4). Comparison of antimicrobial activities of individual SN1 and PTH1 with activity of hybrid SAP against phytopathogens. \% inhibition on the Y-axis refers to CFU for bacteria (C. michiganensis, $P$. syringae pv. syringae, $P$. syringae pv. tabaci) and spore germination for fungus $C$. coccoides. Each result is a mean of three replications. Values are expressed as means $\pm 5 \%$.

treatments at 4 days post inoculation (dpi) by $C$. coccoides as small dry papery spots, regardless of the type of vector used for infection (Fig. 6A-C). These spots were enlarged to 4-6 $\mathrm{mm}$ in diameter at $8 \mathrm{dpi}$ in the "control-mock" and "emptyPVX" treatments, whereas in plants expressing sap gene ("PVX/sap" group) the size of the spots did not exceed from $1 \mathrm{~mm}$ in diameter and remained unchanged for the duration of the experiment (18 dpi). Lesion zones were also observed on stems of the infected plants for all experimental groups (Fig. 6D-F), although the amount and the size of those lesions varied. In "control-mock" and "empty-PVX" groups the number of the stem lesions was $12-15$ per plant with zone sizes ranging from 5 to $7 \mathrm{~mm}$ in diameter, while the stems of sap-expressing plants displayed only 3-5 lesions, ranging from 1 to $2 \mathrm{~mm}$ in diameter. Representative plants from each treatment are shown in (Fig. 6G-I). Plants expressing sap displayed higher levels of resistance to fungal infection than the plants in the control groups ("control-

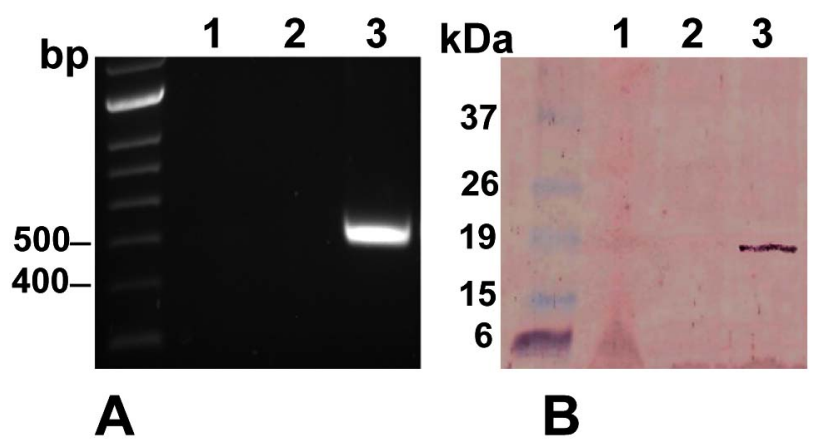

Fig. (5). Detection of the sap gene and its expression in agroinfiltrated tobacco plants. A: RT-PCR analysis of total cellular RNA extracted from systemically infected leaves $\left(7^{\text {th }}\right.$ day after agroinfiltration). Lane 1: "control-mock"; lane 2:"empty-pGR107"; lane 3: "pGR107/sap". B: Western blot analysis of total protein fraction extracted from systemically infected leaves $\left(49^{\text {th }}\right.$ day after agroinfiltration). Lane 1: "control-mock"; lane 2: "empty-pGR107"; lane 3: "pGR107/sap". The blot was incubated with anti-SN1PTH1 polyclonal antisera followed by alkaline phosphatase-conjugated antirabbit sera. mock" and "empty-PVX"). The most severe symptoms were observed in plants of "empty-PVX" group (Fig. 6H) that developed coalescing lesions leading to complete death of the affected leaves. C. coccoides was isolated from the surface of the infected leaves of the $N$. benthamiana and the re-isolated fungus appeared identical to that of the original culture used for inoculation. Conidia from the re-isolated fungus were also able to infect tobacco seedlings.

Examination of conidia of $C$. coccoides was performed after staining of tobacco leaf segments with lactophenol cotton blue solution (Fig. 7). Germination of conidia and appearance of appressoria were detected within $24 \mathrm{~h}$ after inoculation (Fig. 7A,B) on all plants. However, on plants expressing sap ("PVX/sap"), only single conidia germinated, whereas the majority of the conidia did not germinate and were localized along the plant cell wall (Fig. 7C). In the same group ("PVX/sap"), appressorium formation was observed only at few instances. Development of acervuli was detected in all experimental groups on the 5 th dpi (Fig. 7D).

Expression of the Sap Gene in Plants of $S$. Tuberosum and Analysis of Antibacterial Activity of SAP Protein Against C. Michiganensis in in Vivo

For in vivo experiments with potato plants we utilized the same sap gene expression cassette in the context of the PVX-based vector $\mathrm{pP} 2 \mathrm{C} 2 \mathrm{~S}$ as for experiments with tobacco plants described above (Fig. 1B). We attempted several times unsuccessfully to perform agroinfiltration with the pRG107/sap on potato leaves. Due to technical difficulties, we proceeded further with the $\mathrm{pP} 2 \mathrm{C} 2 \mathrm{~S} /$ sap experiments. The stability of the sap gene in $\mathrm{pP} 2 \mathrm{C} 2 \mathrm{~S}$ in potato plants was confirmed by RT-PCR assays using RNA samples isolated from systemically infected leaves and tubers 2 and 8 weeks after transcript inoculation, respectively (Fig. 8A,B). However, as in the case of tobacco plants infected by $\mathrm{pP} 2 \mathrm{C} 2 \mathrm{~S}$, no detectable level of SAP protein in potato plants was observed (data not shown).

The following experimental groups for antibacterial assays were used: 1) "control-mock" (plant + C. michiganensis); 2) "empty-pP2C2S" (plant + pP2C2S + C. michiganensis) and 3) "pP2C2S/sap" (plant + pP2C2S/sap + C. michiganensis $)$. 


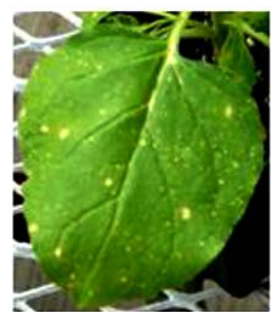

A

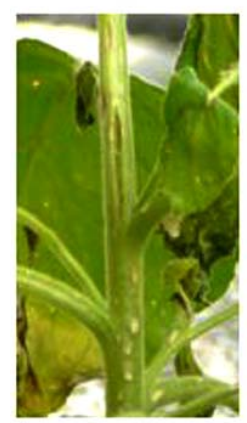

D

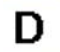

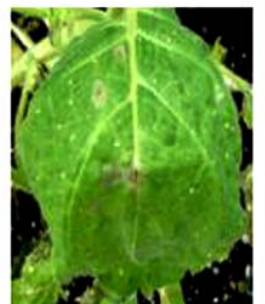

B

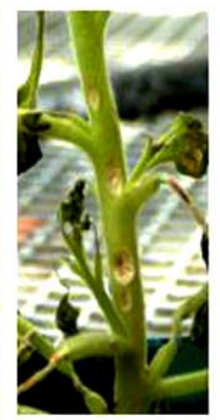

E

$F$

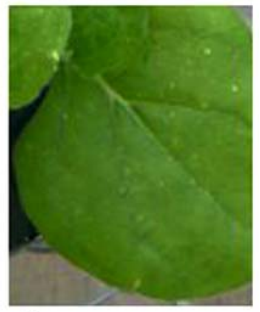

C

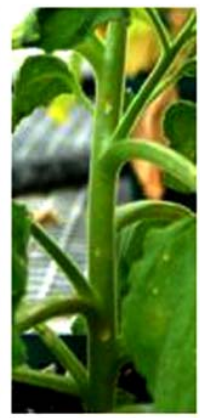

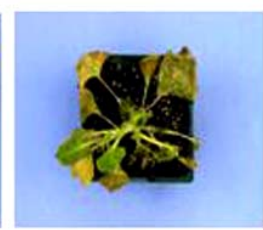

H

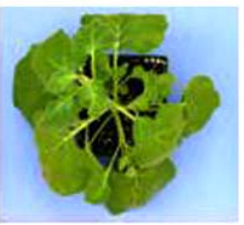

I

Fig. (6). Anthracnose symptoms on tobacco plants inoculated by C. coccoides. Fully expanded leaves of "control-mock" (A), "empty$\mathrm{pP} 2 \mathrm{C} 2 \mathrm{~S}$ " (B) and "pP2C2S/sap" (C) groups ( $9^{\text {th }}$ day after fungal inoculation). The fragments of the tobacco stems of "control-mock" (D), "empty-pP2C2S" (E) and "pP2C2S/sap" (F) groups (12 th day after fungal inoculation). Representative tobacco plants from "control-mock" $(\mathbf{G})$, “empty-pP2C2S" $(\mathbf{H})$ and "pP2C $2 \mathrm{~S} /$ sap" (I) groups (12 ${ }^{\text {th }}$ day after fungal inoculation).

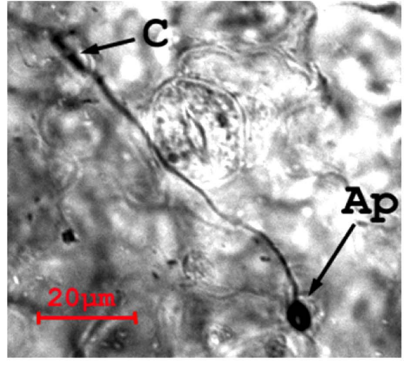

A

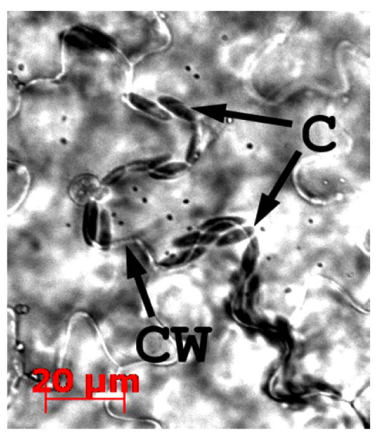

C

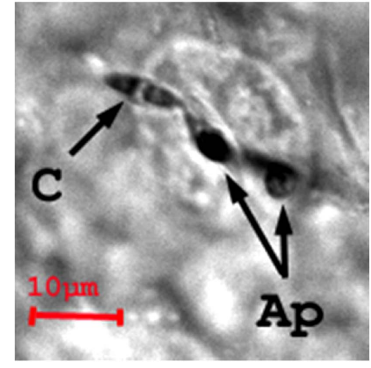

B

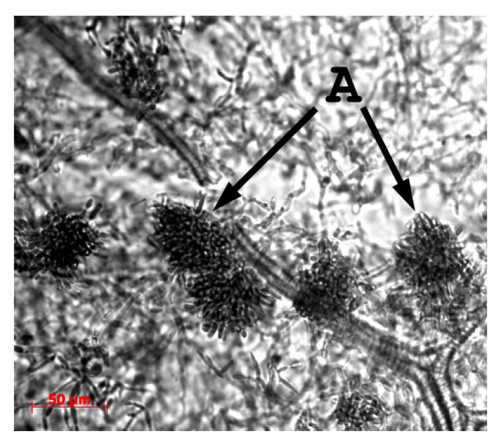

D

Fig. (7). Sections of the tobacco leaf surfaces stained with lactophenol cotton blue solution. Germination of conidia (C) of $C$. coccoides with appressorium (Ap) formation in "control-mock" (A) and "empty-pGR107" (B) groups (2nd dpi). C: specific localization of fungal conidia along the plant cell wall (CW) in "pP2C2S/sap" group (2nd dpi). D: Acervulus (A) development in "control-mock" group (5 $5^{\text {th }}$ dpi). 

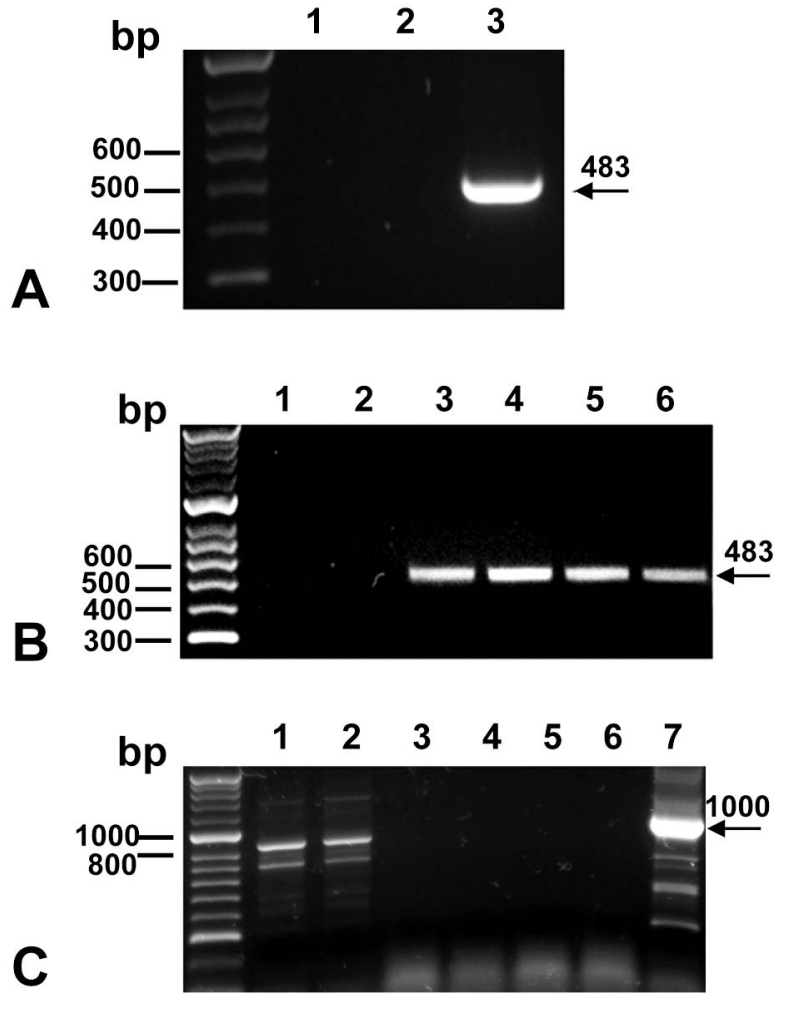

Fig. (8). Molecular analysis of potato plants. RT-PCR analysis using primers SN1F/PTH1R of RNA samples isolated from the systemically infected leaves (A) $\left(14^{\text {th }}\right.$ day after rub-infection) and tubers (B) $\left(56^{\text {th }}\right.$ day after rub-infection). C: PCR analysis of DNA samples isolated from the infected tubers with primer pairs specific to $C$. michiganensis subsp. sepedonicus genome $\left(40^{\text {th }}\right.$ dpi by $C$. michiganensis). Lane 1: "control-mock", lane 2: "empty-pP2C2S", lanes 3-6: "pP2C2S/sap", lane 7: C. michiganensis (positive control). $\mathrm{bp}=$ AlphaQuant ${ }^{\mathrm{TM}} 2$ (Alpha Innotech). Arrows indicate the size of the expected PCR amplicon in base pairs.

Symptoms of potato ring rot disease were observed on potato plants in "control-mock" and "empty-pP2C2S" groups (Fig. 9A-C) whereas no notable disease symptoms appeared on plants expressing sap ("pP2C2S/sap") (Fig. 9H). Bacterium inoculation techniques of the plants did not affect the infection rate or appearance of symptoms (Experimental Procedures). Above-ground symptoms were observed after approximately 3 weeks post-bacterial inoculation. The initial foliar symptoms included: wilting, yellowing at the leaf margins followed by leaf rolling (Fig. 9B) and subsequent necrosis of terminal leaves and stems (Fig. 9C). In most cases the above-ground symptoms were limited to two stems in a hill while the rest of the stems appeared normal. Furthermore, the brown necrotic spots were detected on the stems of the plants in "empty-pP2C2S" group (Fig. 9C).

Tuber symptoms appeared later and were clearly visible after 6 weeks post-bacterial inoculation in the "control-mock" group (Fig. 9D,E), whereas no tuber symptoms in other experimental groups ("empty-pP2C2S" and "pP2C2S/sap") were observed (data not shown). The external tuber symptoms included the appearance of yellowish zones on the surface of the tubers covered with mucus (Fig. 9D). The internal tuber symptoms involved changes in the color of vascular ring from cream to brown, development of significant creamy bacterial ooze in place of infection, and disintegration of the inner part of the tubers except its outer shell (Fig. 9E).

To test the presence of $C$. michiganensis in potato tubers, a detection procedure based on PCR amplification of $C$. michiganensis subsp. sepedonicus -specific DNA was employed [54, 55]. No C. michiganensis subsp. sepedonicus -specific amplicons were detected when DNA samples isolated from tubers expressing the sap gene were used as a template, while such amplicons were detected from samples in "control-mock" and "empty-pP2C2S" groups (Fig. 8C).

A sample of infected potato plants is shown in (Fig. 9FH). Plants expressing sap ("pP2C2S/sap" group) (Fig. 9H) exhibited a significantly higher level of resistance to bacterial infection as compared to the plants from "control-mock" and "empty-pP2C2S" groups (Fig. 9F-G) and were indistinguishable from uninfected healthy plants (Fig. 9I).

\section{DISCUSSION}

In this work, we constructed a hybrid protein SAP consisting of two mature antimicrobial proteins $\mathrm{SN} 1$ and PTH1 of plant origin linked by autocatalytic cleavage site (FMDV 2A protease) and demonstrated its antibacterial and antifungal activities against phytopathogens in in vitro and in vivo.

The successful production of individual SN1 and PTH1 for in vitro experiments using a $\mathrm{pET}$-expression system was demonstrated previously in our laboratory [31]. In the present study, we used the same prokaryotic expression system to produce a hybrid protein. In spite of the presence in the pET-vector of an N-terminal pelB signal sequence fused to the expressed protein, which should facilitate protein localization to the periplasm and reduce or eliminate IB formation, electrophoretic analysis of the total and soluble fractions of bacterially-expressed SAP revealed that the hybrid protein was localized in the form of insoluble aggregates (e.g. IBs) (Fig. 2A). It has been reported that adjustment of the IB washing condition allows isolation of IBs containing more than $90 \%$ of pure recombinant protein [57]. We used the advantage of IB formation and successfully obtained a purified SAP protein for microbiological assays.

In our experiments, we expected to generate two individual proteins SN1 and PTH1 from the hybrid, but no visible cleavage products were detected both in prokaryotic and eukaryotic expression systems. The reason for the inability of the FMDV 2A oligopeptide to mediate cleavage in a prokaryotic system is not clear. Although the complete FMDV 2A protease was reported not to function in prokaryotes while it does function in eukaryotes [58], the 2A oligopeptide is predicted to function autocatalytically and may not require host cell proteases for cleavage $[56,59,60]$.

In vitro experiments demonstrated that antimicrobial activity of the hybrid protein against $P$. syringae $p v$. syringae, $P$. syringae $p v$. tabaci and $C$. coccoides was higher than the activity of individual SN1 and PTH1 proteins [31] (Fig. 4). While SAP completely inhibited spore germination of $C$. coccoides at $6 \mu \mathrm{M}$, the same effect for individual SN1 and PTH1 was achieved only at $14 \mu \mathrm{M}$. A clear additive effect of SN1 and PTH1 proteins in the form of a hybrid was also demonstrated for pseudomonads: a $6 \mu \mathrm{M}$ of SAP led to 


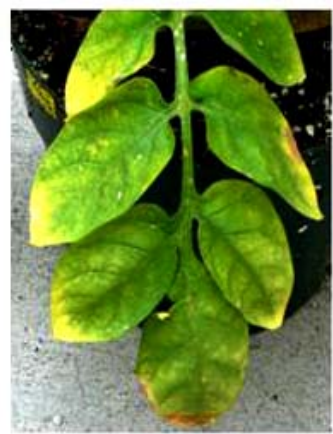

A

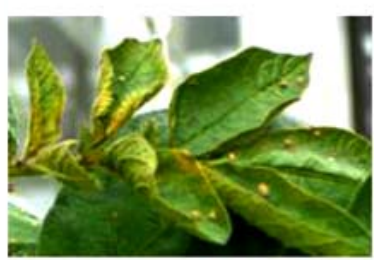

B

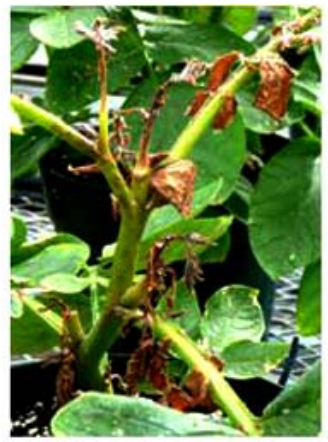

C
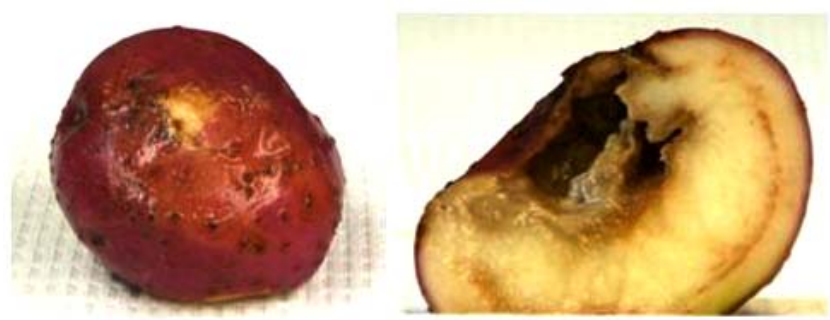

E

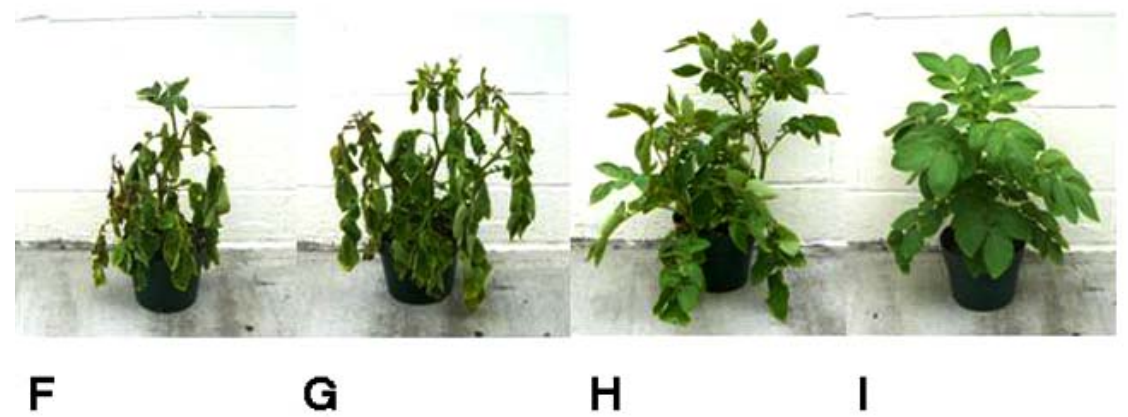

Fig. (9). Foliar and tuber symptoms of potato ring rot disease, caused by C. michiganensis. Above-ground symptoms of potato ring rot disease on plants of "control-mock" (A-B) and "empty-pP2C2S" groups (C) (37/28 dpi, respectively; the plants were infected by root trimming). Surface (D) and cross section (E) of the potato infected tuber ("control-mock" group, $46^{\text {th }}$ dpi, plants were inoculated by stem injection). Representative potato plants from "control-mock" (F), "empty-pP2C2S" (G), "pP2C2S/sap" (H) groups $\left(37^{\text {th }}\right.$ dpi, plants were infected by root trimming). I: healthy plant (without any treatment).

about $25 \%$ and $35 \%$ inhibition of $P$. syringae pv. syringae and $P$. syringae pv. tabaci, respectively, whereas individual SN1 and PTH1 at concentration of $6 \mu \mathrm{M}$ each inhibited growth of pathogen by approximately $10 \%$ [31]. The effect of SAP on growth of $C$. michiganensis was comparable to the effect of PTH1 alone; however, aggregation of the bacterial cells in cultures of $C$. michiganensis by SAP was similar to that observed with SN1 alone [31], indicating that, despite the observation that the hybrid protein was not cleaved at the 2A oligopeptide cleavage site, the SN1 protein retained its activity in the hybrid protein.

Despite the absence of expected SAP self-cleavage in plant tissues and detectable level of SAP protein in transcriptinoculated tobacco and potato plants ("pP2C2S/sap" groups), our in vivo experiments demonstrated a clear antimicrobial effect of SAP against $C$. coccoides and $C$. michiganensis (Fig. 6 - Fig. 9). We suggest that the presence of the linker (FMDV 2A region) in SAP protein does not affect folding of SN1 and PTH1 components of the hybrid, which allows them to remain functionally active in the hybrid protein. The inability of 2A protein to undergo self-cleavage in plant cells in our in vivo experiments remains unclear, though, according to the literature data, the $2 \mathrm{~A}$ protein has been used for a variety of biotechnological purposes and its activity has been examined in a wide range of heterologous protein contexts, so it should be active in all eukaryotic systems $[48,58-60]$.

The absence of a detectable level of SAP protein in tobacco and potato plants infected by vector pP2C2S carrying sap gene indicates a low level of sap gene expression or protein degradation. Low levels of gene expression may be due to activation of a post-transcriptional gene silencing (PTGS) mechanism whereby homology between nucleotide sequences of the sap gene on the virusbased vector and a gene/genes on the chromosome of hostplant results in degradation of viral RNA transcripts [61, 62]. This explanation is based on our supposition that tobacco may produce antimicrobial proteins in composition to SN1 and PTH1 to those that are present in potato, which are both members of the Solanaceae. In contrast, the expression of 
sap gene in tobacco plants was confirmed for Agrobacteriummediated gene transfer. In this case, we employed the advantage of Agrobacterium system [63] and co-expressed in tobacco plants sap gene and $p 19$ gene encoding the p19 protein of Tomato bushy stunt virus (TBSV), a powerful silencing suppressor protein [64-66], to boost production of the SAP protein.

Although the appearance of anthracnose symptoms on tobacco plants, caused by the fungus $C$. coccoides, was observed in all experimental groups, the severity was significantly lower in plants expressing sap gene (Fig. 6). These data strongly suggest a plant protective role of SAP protein against fungal infection.

The hybrid protein showed antibacterial properties in in vivo as well. No visible above-ground or tuber symptoms of the potato ring rot disease, caused by bacteria $C$. michiganensis, were observed in potato plants expressing sap (Fig, 9). Though, there were also no tuber symptoms on the plants expressing the "empty-pP2C2S" cassette, but the foliar symptoms in this case were clearly visible. Both above-ground and tuber symptoms were observed in "control-mock" group. According to the literature, symptoms in infected tubers may or may not develop after 2-3 months of infected tubers storage [67]. Moreover, foliar and tuber symptoms of the bacterial ring rot disease vary depending on the potato cultivar, while most plants rarely exhibit any symptoms upon infection [68]. PCR analysis of DNA isolated from potato tubers showed the absence of $C$. michiganensis subsp. sepedonicus-specific DNA in plants expressing sap gene, but it was detected in plants without sap expression (Fig. 8). The hybrid SAP protein may impede the spread of bacterial cells from inoculation sites and prevent systemic infection by causing rapid aggregation of bacterial cells. We previously demonstrated the ability of the $\mathrm{SN} 1$ protein to aggregate cells of $C$. michiganensis in in vitro $[31,35]$.

In summary, our study showed: a) the ability to obtain a functionally active SAP protein from purified IBs, suitable for in vitro biological characterization; b) the higher effectiveness of the hybrid protein against the majority of the tested microorganisms in in vitro as compared with the activity of individual SN1 and PTH1 proteins, and c) the plant protective properties of SAP protein against anthracnose and potato ring rot disease.

The findings from the present work suggest that in vivo co-production of recombinant SN1 and PTH1 in the form of hybrid protein is a promising strategy for antimicrobial plant defense applications.

\section{ACKNOWLEDGEMENTS}

We thank Dr. C.J. Baker and Dr. I.-M. Lee (Molecular Plant Pathology Laboratory, United States Department of Agriculture, Beltsville, MD, U.S.) for the gifts of Pseudomonas and Clavibacter phytopathogenic bacterial strains, respectively, and technical support. We acknowledge Dr. R. Jones (Genetic Improvement of Fruit and Vegetables Laboratory, United States Department of Agriculture, Beltsville, MD, U.S.) for the gift of the phytopathogenic fungal strain Colletotrichum coccoides. The respective pathogens remained under control of the donor laboratories. We also thank Dr. L. Nemchinov (Molecular Plant Pathology Laboratory, United States Department of Agriculture, Beltsville, MD, U.S.) for helpful discussions, and Dr. A. Borovjagin (Institute of Oral Health Research Department of Periodontics UAB School of Dentistry, University of Alabama at Birmingham, AL, U. S.) who assisted in the preparation of this manuscript. USDA is an equal opportunity provider and employer.

\section{REFERENCES}

[1] Manners JM. Hidden weapons of microbial destruction in plant genomes. Genome Biol 2007; 8: 225.

[2] Mittler R, Vanderrauwera S, Gollery M, Van Breusegem F. Reactive oxygen network of plants. Trends Plant Sci 2004; 9: 490-8.

[3] Van der Hoorn RAL, Laurent F, Roth, R, De Wit PJGM. Agroinfiltration is a versatile tool that facilitates comparative analyses of Avr9/Cf-9-induced and Avr4/Cf-4-induced necrosis. Mol. Plant-Microbe Interact 2000; 13: 439-46

[4] Montesinos E. Antimicrobial peptides and plant disease control. FEMS Microbiol Lett 2007; 270: 1-11.

[5] Xu X, Jin F, Yu X, Ren S, Hu J, Zhang W. High-level expression of the recombinant hybrid peptide cecropinA (1-8)-magainin2 (1-12) with an ubiquitin fusion partner in Escherichia coli. Protein Expr Purif 2007; 55: 175-82.

[6] Matsuzaki K. Why and how are peptide-lipid interactions utilized for self defense? Biochem Soc Trans 2001; 29: 598-601.

[7] Ferre R, Badosa E, Feliu L, Planas M, Montesinos E, Bardaji E. Inhibition of plant-pathogenic bacteria by short synthetic cecropin A-melittin hybrid peptides. Appl Environ Microbiol 2006; 72: 3302-8.

[8] Oard SV, Enright FM. 2006. Expression of the antimicrobial peptides in plants to control phytopathogenic bacteria and fungi. Plant Cell Rep 2006; 25: 561-72.

[9] Thevissen K, Ferket KK, Francois IE, Cammue BP. Interactions of antifungal plant defensins with fungal membrane components. Peptides 2003; 24: 1705-12.

[10] Uematsu N, Matsuzaki K. Polar angle as a determinant of amphipathic $\alpha$-helix-lipid interactions: a model peptide study. Biophys J 2000; 79: 2075-83.

[11] Duquesne S, Destoumieux-Garzon D, Peduzzi J, Rebuffat. S. Microcins, gene-encoded antibacterial peptides from enterobacteria. Nat Prod Rep 2007; 24: 708-34.

[12] Montesinos E, Bardaji E. Synthetic antimicrobial peptides as agricultural pesticides for plant-disease control. Chem Biodivers 2008; 5: 1225-37.

[13] Zhang B, Xie C, Yang X. A novel small antifungal peptide from bacillus strain B-TL2 isolated from tobacco stems. Peptides 2008; 29: 350-5.

[14] Berrocal-Lobo M, Segura A, Morena M, López G, García-Olmedo F, Molina A. Snakin-2, an antimicrobial peptide from potato whose gene is locally induced by wounding and responds to pathogen infection. Plant Physiol 2002; 128: 951-61.

[15] Choi HW, Lee, BG, Kim NH, et al. A role for a menthone reductase in resistance against microbial pathogens in plants. Plant Physiol 2008; 148: 383-401.

[16] Coca M, Peñas G, Gómez J, et al. Enhanced resistance to the rice blast fungus Magnaporthe grisae conferred by expression of a cecropin A gene in transgenic rice. Planta 2006; 223: 392-406.

[17] Egorov TA, Odintsova TI, Pukhalsky VA, Grishin EV. Diversity of wheat anti-microbial peptides. Peptides 2005; 26: 2064-73.

[18] Franco OL, Murad AM, Leite JR, Mendes PA, Prates MV, Bloch C. Identification of cowpea gamma-thionin with bactericidal activity. FEBS J 2006; 273: 3489-97.

[19] Lipkin A, Anisimova V, Nikonorova A, et al. An antimicrobial peptide Ar-AMP from amaranth (Amaranthus retroflexus L.) seeds. Phytochemistry 2005; 66: 2426-31. 
[20] Pelegrini PB, Noronha EF, Muniz MA, et al. An antifungal peptide from passion fruit (Passiflora edulis) seeds with similarities to $2 \mathrm{~S}$ albumin proteins. Biochim Biophys Acta 2006; 1764: 1141-6.

[21] Sitaram N. Antimicrobial peptides with unusual amino acid compositions and unusual structures. Curr Med Chem 2006; 13: 679-96.

[22] Thomma BP, Cammue BP, Thevissen K. Plant defensins. Planta 2002; 216: 193-202.

[23] Wong JH, Xia L, Ng TB. A review of defensins of diverse origins. Curr Protein Pept Sci 2007; 8: 446-59.

[24] Zasloff M. Magainins, a class of antimicrobial peptides from Xenopus skin: isolation, characterization of two active forms, and partial cDNA sequence of a precursor. Proc Natl Acad Sci USA 1987; 84: 5449-53.

[25] Zhou QF, Luo XG, Ye L, Xi T. High-level production of a novel antimicrobial peptide perinerin in Escherichia coli by fusion expression. Curr Microbiol 2007; 54: 366-70.

[26] Donini M, Lico C, Baschieri S, et al. Production of an engineered killer peptide in Nicotiana benthamiana by using a Potato virus $X$ expression system. Appl Environ Microbiol 2005; 71: 6360-7.

[27] Li Q, Lawrence CB, Xing H-Y, et al. Enhanced disease resistance conferred by expression of an antimicrobial magainin analog in transgenic tobacco. Planta 2001; 212: 635-9.

[28] De Lucca AJ, Cleveland TE, Wedge DE. Plant-derived antifungal proteins and peptides. Can J Microbiol 2005; 51: 1001-14.

[29] Hancock EW, Diamond G. The role of cationic antimicrobial peptides in innate host defenses. Trends Microbiol 2000; 8: 402-10.

[30] Hammami R, Hamida JB, Vergoten G, Fliss I. PhytAMP: a database dedicated to antimicrobial plant peptides. Nucleic Acids Res 2008; 37: 963-68.

[31] Kovalskaya N, Hammond RW. Expression and functional characterization of the plant antimicrobial snakin-1 and defensin recombinant proteins. Protein Expr Purif 2009; 63: 12-17

[32] Lee SC, Hwang IS, Choi HW, Hwang BK. Involvement of the pepper antimicrobial protein CaAMP1 gene in broad spectrum disease resistance. Plant Physiol 2008; 148: 1004-20.

[33] Mitsuhara I, Matsufuru H, Ohshima M et al. Induced expression of sacrotoxin $1 \mathrm{~A}$ enhanced host resistance against both bacterial and fungal pathogens in transgenic tobacco. Mol Plant-Microbe Interact 2000; 13: 860-8.

[34] Muñoz A, López-García B, Marcos JF. Comparative study of antimicrobial peptides to control citrus postharvest decay caused by Penicillium digitatum. J Agric Food Chem 2007; 55: 8170-6.

[35] Segura A, Moreno M, Madueno F, Molina A, Garcia-Olmedo F. Snakin-1, a peptide from potato that is active against plant pathogens. Mol Plant-Microbe Interact 1999; 12: 16-23.

[36] Swathi AT, Divya K, Jami SK, Kirti PB. Transgenic tobacco and peanut plants expressing a mustard defensin show resistance to fungal pathogens. Plant Cell Rep 2008; 27: 1777-86.

[37] Vijayan S, Guruprasad L, Kirti PB. Prokaryotic expression of a constitutively expressed Tephrosia villosa defensin and its potent antifungal activity. Appl Microbiol Biotechnol 2008; 80: 1023-32.

[38] Xing H, Lawrence CB, Chambers O, Davies HM, Everett NP, Li QQ. Increased pathogen resistance and yield in transgenic plants expressing combinations of the modified antimicrobial peptides based on indolicidin and magainin. Planta 2006; 223: 1024-32.

[39] Barrell PJ, Conner AJ. Expression of a chimeric magainin gene in potato confers improved resistance to the phytopathogen Erwinia carotovora. Open Plant Sci J 2009; 3: 14-21.

[40] Jach G, Görnhardt B, Mundy J, et al. Enhanced quantitative resistance against fungal disease by combinatorial expression of different antifungal proteins in transgenic tobacco. Plant J 1995; 8: 97-109.

[41] Zhu Q, Maher EA, Masoud S, Dixon RA, Lamb CJ. Enhanced protection against fungal attack by constitutive co-expression of chitinase and glucanase genes in transgenic tobacco. Bio Technology 1994; 12: 807-12.

[42] Hongbiao W, Baolong N, Mengkui X, Lihua H, Weifeng S, Zhiqi M. Biological activities of cecropin B-thanatin hybrid peptides. J. Peptide Res 2005; 66: 382-6.
[43] Broekaert WF, Terras FRG, Cammue BPA, Osborn RW. Plant defensins: Novel antimicrobial peptides as components of the host defense system. Plant Physiol 1995; 108: 1353-8.

[44] Saitoh H, Kiba A, Nishihara M, Yamamura S, Suzuki K, Terauchi R. Production of antimicrobial defensin in Nicotiana benthamiana with a Potato virus X vector. Mol Plant-Microbe Interact 2001; 14: 111-5.

[45] Chapman S, Kavanagh T, Baulcombe D. Potato virus X as a vector for gene expression in plants. Plant J 1992; 2: 549-57.

[46] Lacomme C, Chapman S. Use of Potato Virus X (PVX)-based vectors for gene expression and virus-induced gene silencing (VIGS). Curr Protoc Microbiol 2008.8: 16I.1.1-16I.1.13.

[47] Sambrook J, Fritsch EF, Maniatis T. Molecular cloning: a laboratory manual. $2^{\text {nd }}$ Ed. Cold Spring Harbor Laboratory Press. Cold Spring Harbor, NY. 1989; p. 1659.

[48] Ryan MD, King AMQ, Thomas GP. Cleavage of foot-and-mouth disease virus polyprotein is mediated by residues located within a 19 amino acid sequence. J Gen Virol 1991; 72: 2727-32.

[49] Bradford MM. A rapid and sensitive method for the quantitation of microgram quantities of protein utilizing the principle of proteindye binding. Anal Biochem 1976; 72: 248-54.

[50] Bragg JN, Jackson AO. The C-terminal region of the Barley stripe mosaic virus $\gamma$ b protein participates in homologous interactions and is required for suppression of RNA silencing. Mol Plant Pathol 2004; 5 : 465-81.

[51] King EO, Ward MK, Raney DE. Two simple media for demonstration of pycocyanin and fluorescin. J Lab Clin Med 1954; 44: 301-7.

[52] Lin J-J, Kuo J. A new reagent for simple isolation of plant genomic DNA. Focus 1998; 20: 46.

[53] Lee I-M,Bartoszyk IM, Gundersen DE, Mogen B, Davis RE. Nested PCR for ultrasensitive detection of the potato ring rot bacterium, C. michiganensis subs. Sepedonicus. Appl Environ Microbiol 1997; 63: 2625-30.

[54] Chuang L-Y. Insertion sequence-targeted approaches to detection and differentiation of strain of $C$. michiganensis subspecies sepedonicus. PhD dissertation. North Dakota State University, Fargo, 1994.

[55] Mogen BD, Oleson AE, Sparks RB, Gudmestad NC, Secor GA. Distribution and partial characterization of pCS1, a highly conserved plasmid present in C. michiganensis subs. sepedonicus. Phytopathology 1988; 78: 1381-6.

[56] Ryan MD, Drew J. Foot-and-mouth disease virus 2A oligopeptide mediated cleavage of an artificial polyprotein. EMBO J 1994; 13 : 928-33.

[57] Sambrook J, Russell DW. Molecular cloning: a laboratory manual. 3rd ed. Cold Spring Harbor Laboratory Press: Cold Spring Harbor, NY. 2001; vol. 3: pp. 15-49.

[58] Donnelly MLL, Hughes LE, Luke G, et al. The 'cleavage' activities of foot-and-mouth disease virus $2 \mathrm{~A}$ site-directed mutants and naturally occurring '2A-like' sequences. J Gen Virol 2001; 82: $1027-41$.

[59] Ryan MD, Belsham GJ, King AMQ. Specificity of enzymesubstrate interactions in foot-and-mouth disease virus polyprotein processing. Virology 1989; 173: 35-45.

[60] Donnelly MLL, Gani D, Flint M, Monoghan S, Ryan MD. The cleavage activity of aphtho- and cardiovirus $2 \mathrm{~A}$ proteins. J Gen Virol 1997; 78: 13-21.

[61] Hammond SM, Caudy AA, Hannon GJ. Post-transcriptional gene silencing by double-stranded RNA. Nat Rev Genet 2001; 2 : 110-19.

[62] Voinnet O. RNA silencing as a plant immune system against viruses. Trends Genet 2001; 17: 449-59.

[63] Kapila J, De Rycke R, Van Montagu M, Angenon G. An Agrobacterium-mediated transient gene expression system for intact leaves. Plant Sci 1997; 122: 101-8.

[64] Brigneti G, Voinnet O, Li W-X, Ji L-H, Ding S-W, Baulcombe DC. Viral pathogenicity determinants are suppressors of transgene silencing in Nicotiana benthamiana. EMBO J 1998; 17: 6739-46. 
[65] Johansen LK, Carrington JC. Silencing on the spot. Induction and suppression of RNA silencing in the Agrobacterium-mediated transient expression system. Plant Physiol 2001; 126: 930-8.

[66] Voinnet O, Rivas S, Mestre P, Baulcombe D. An enhanced transient expression system in plants based on suppression of gene silencing by the $\mathrm{p} 19$ protein of tomato bushy stunt virus. Plant $\mathrm{J}$ 2003; 33: 949-56.
[67] Gudmestad NC, Secor GA. In: Rowe RC, Ed. Management of soft rot and ring rot. Potato health management. APS Press. St. Paul, MN 1993; pp. 135-9.

[68] Guide to Commercial Potato production on the Canadian prairies Western Potato Council, Portage La Prairie, Manitoba, Canada. 2003; p. 107

Received: May 18, 2011

Revised: June 21, 2011

Accepted: July 04, 2011

(C) Kovalskaya et al.; Licensee Bentham Open.

This is an open access article licensed under the terms of the Creative Commons Attribution Non-Commercial License (http://creativecommons.org/licenses/by$\mathrm{nc} / 3.0 /$ ) which permits unrestricted, non-commercial use, distribution and reproduction in any medium, provided the work is properly cited. 